\title{
CORTICOTROPIN-RELEASING FACTOR DESENSITIZATION OF ADRENOCORTICOTROPIC HORMONE RELEASE IS AUGMENTED BY ARGININE VASOPRESSIN ${ }^{1}$
}

\author{
ANDREW R. HOFFMAN, ${ }^{* 2}$ GIANPAOLO CEDA,* AND TERRY D. REISINE $\ddagger$ \\ * Division of Endocrinology, Stanford University Medical Center, Stanford, California 94305 and $\ddagger$ Laboratory of Clinical \\ Sciences, National Institute of Mental Health, Bethesda Maryland 20205
}

Received April 16, 1984; Accepted June 22, 1984

\begin{abstract}
The desensitization of corticotropin-releasing factor (CRF)-stimulated ACTH release from and intracellular cyclic AMP accumulation in anterior pituitary cells was investigated in primary cultures of rat pituitary cells and in a mouse tumor cell line (AtT 20/D16-16). CRF potently stimulated ACTH secretion and cyclic AMP accumulation in both preparations. When primary cultures were preincubated with $100 \mathrm{nM}$ CRF, $50 \%$ desensitization of ACTH release occurred within $4 \mathrm{hr}$ while similar desensitization of cyclic AMP accumulation occurred by $1 \mathrm{hr}$. This desensitization was manifested as a reduced maximal CRF response. Concentrations of $\mathrm{CRF}$ as low as 1 to $10 \mathrm{pM}$ induced desensitization. Pretreatment did not affect ACTH content nor did it alter the ability of epinephrine or forskolin to stimulate ACTH release. Pretreatment of AtT 20 cells, which are a homogeneous population of corticotrophs, with $100 \mathrm{nM}$ CRF reduced the subsequent ability of CRF, but not of isoproterenol or of forskolin, to stimulate ACTH release and cyclic AMP formation. Preincubation of AtT 20 cells with isoproterenol did not affect the cyclic AMP or ACTH release responses induced by CRF, but did desensitize $\beta$-adrenergic receptors. Arginine vasopressin (AVP) was a weak ACTH-releasing factor, but AVP enhanced CRF-directed ACTH release from primary cultures. When these cells were preincubated with both CRF and AVP, CRF desensitization occurred with lower concentrations of CRF than when CRF desensitization was induced by preincubating the cells with $\mathrm{CRF}$ alone. $\mathrm{The}_{\mathrm{ED}}$ for $\mathrm{CRF}$-induced desensitization was $700 \pm$ $150 \mathrm{pM}$ when the cells were exposed to CRF alone, and $20 \pm 15 \mathrm{pM}$ when $1 \mu \mathrm{M}$ AVP was added during the preincubation. This enhancement of CRF desensitization was also seen when lower concentrations of AVP were added. In conclusion: (1) ovine CRF rapidly desensitizes its ability to stimulate ACTH secretion and cyclic AMP accumulation in primary monolayer cultures of rat pituitary cells and in cultured mouse pituitary tumor cells; (2) this desensitization is specific, allowing the cells to respond to other ACTH-secretagogues; (3) AVP enhances the ability of CRF to stimulate ACTH release from primary cultures during brief incubation periods; and (4) CRF desensitization is augmented when primary cultures of rat pituitary cells are preincubated with both CRF and AVP.
\end{abstract}

Corticotropin-releasing factor (CRF), a 41-amino acid peptide recently isolated from sheep (Vale et al., 1981) and rat (Rivier et al., 1983) hypothalami, is the most potent of the various characterized ACTH-secretagogues. While both in vitro and in vivo experiments indicate that CRF is the most important stimulator of the pituitary corticotroph, it is becoming increasingly apparent that other neurohormones may have substantial modulating effects on ACTH release (Vale et al., 1983). Thus, arginine vasopressin (AVP) (Yates et al., 1971; Giguere and Labrie, 1982; Gillies et al., 1982; Gillies and Lowry, 1982; Labrie et al., 1982; Aguilera et al., 1983; Rivier and Vale,

\footnotetext{
${ }^{1}$ Supported by National Institutes of Health Grant AG01312, Biomedical Research Grant RR5353, and a grant from the Institute of Clinical and Biological Sciences, Department of Medicine, Stanford University, A. R. H. is an Alfred P. Sloan Fellow. A preliminary report of these data was delivered at the 65th Annual Meeting of the Endocrine Society at San Antonio, TX in June 1983.

${ }^{2}$ To whom correspondence should be addressed.
}

1983b; Vale et al., 1983) and epinephrine (Aguilera et al., 1983; Giguere and Labrie, 1983; Vale et al., 1983) both enhance the ability of CRF to secrete ACTH, while somatostatin (Heisler et al., 1982) muscarinic agonists (Heisler et al., 1983a) and glucocorticoids (Giguere et al., 1982; Reisine et al., 1982; Bilezikjian and Vale, 1983) can inhibit CRF-directed corticotropin release. Adding to the complexity of this multihormonal control mechanism are our recent in vitro observations that the stimulating effects of catecholamines (Heisler et al., 1983b) and the inhibitory actions of somatostatin (Reisine and Axelrod, 1983) are readily, reversibly, and specifically desensitized. This desensitization occurs both for ACTH release and for intracellular accumulation of cyclic AMP, a putative mediator of corticotropin secretion. Since CRF is the major central stimulant of $\mathrm{ACTH}$ release, changes in the sensitivity of corticotrophs to CRF may be important with regard to the adaptability of the organism following chronic forms of stress.

Recent evidence suggests that $\mathrm{CRF}$ responsiveness is in fact regulated. Prior administration of $\mathrm{CRF}$ to rats reduces the subsequent ability of CRF to elicit an ACTH secretory response (Rivier and Vale, 1983a). In a preliminary study (Reisine and 
Hoffman, 1983), we suggested that CRF desensitization can occur at the level of the anterior pituitary. Since the adenohypophysis consists of many cell types of which only a small percentage are ACTH-secreting cells, we have now utilized a cell line derived from a mouse anterior pituitary tumor (AtT 20/D16-16) which consists of a homogeneous population of ACTH-secreting cells in order to show that CRF desensitization takes place at the corticotroph itself.

The discovery that CRF and AVP may be co-localized within the same hypothalamic neurons (Roth et al., 1982) suggests that the two ACTH-secretagogues might also be co-secreted and thereby act in concert. It has recently been shown that adrenalectomy, a procedure which markedly enhances ACTH release, dramatically increases the number of paraventricular neurons which contain both CRF and AVP (Kiss et al., 1984). Several groups have now shown that AVP has an additive, if not synergistic, effect on CRF-directed ACTH release. If CRF and AVP are in fact secreted simultaneously, it would be of interest to learn whether AVP also affects the process of CRF desensitization. In this report, we demonstrate the ability of AVP to enhance the process of CRF desensitization in primary cultures of anterior pituitary cells.

\section{Materials and Methods}

\section{Anterior pituitary cell culture}

Primary culture. Sexually mature ( 225 to $275 \mathrm{gm}$ ) male SpragueDawley rats were decapitated and the pituitary glands were removed under aseptic conditions. The anterior lobes were dissected free from the posterior and intermediate lobes and minced with a sterile surgical blade. The pituitary fragments were incubated at $37^{\circ} \mathrm{C}$ in $0.25 \%$ trypsin without FDTA (GIBCO, Grand Island, NY), $0.3 \mathrm{mg} / \mathrm{ml}$ of collagenase (Worthington Diagnostic Systems, Inc., Freehold, NJ), and $1 \%$ antibiotics; $50 \mu \mathrm{l}$ of DNase, $1 \mathrm{mg} / \mathrm{ml}$ (Worthington), was added after 15 to $20 \mathrm{~min}$. Dispersion of cells was augmented by triturating the fragments through a sterile pipette tip. After 60 to $90 \mathrm{~min}$, the cells were pelleted by centrifugation, washed three times in sterile Dulbecco's modified Eagle's medium (DMEM) (1000 mg of glucose $/ \mathrm{ml}$ ) and then plated at a density of 200,000 cells/well in $2-\mathrm{cm}^{2}, 24$-well plastic cluster dishes (Costar, Cambridge, MA) in DMEM with $10 \%$ heat-inactivated fetal calf serum (GIBCO), streptomycin $(50 \mu \mathrm{g} / \mathrm{ml})$, penicillin (50 units $/ \mathrm{ml}$ ), and Fungizone $(2.5 \mu \mathrm{g} / \mathrm{ml})$. Cell cultures were incubated at $37^{\circ} \mathrm{C}$ in a humidified atmosphere of $90 \%$ air $10 \% \mathrm{CO}_{2}$ for 3 to 4 days.

AtT 20 cells. Mouse AtT 20/D16-16 tumor cells were grown and subcultured in DMEM $(4500 \mathrm{mg}$ of glucose $/ \mathrm{ml})$ with $10 \%$ fetal calf serum as previously described (Heisler et al., 1982). Cells that were used for the cyclic AMP studies were plated in $35-\mathrm{mm}$ diameter culture cluster dishes at an initial density of $1.5 \times 10^{5}$ cells/well and were used 5 days after subculturing ( 60 to $80 \%$ confluency).

\section{Densensitization experiments in primary pituitary cell culture}

Three to 4 days following cell plating, the medium in the wells was removed and $1 \mathrm{ml}$ of fresh DMEM containing $2 \%$ fetal calf serum, 3 $\mu \mathrm{g} / \mathrm{ml}$ of bacitracin, and $25 \mathrm{~mm}$ Hepes ( $\mathrm{pH} \mathrm{7.4)}$ ), with or without various hormones, was added to the cells for varying periods of time. During the incubation period, the cells were placed in a humidified atmosphere containing $5 \% \mathrm{CO}_{2}$ at $37^{\circ} \mathrm{C}$. Following the preincubation period, the medium was removed from the cells, and the cells were washed twice with $1 \mathrm{ml}$ of fresh medium free of added hormones. After washing, medium without (basal secretion) or with various test agents were added to the cells for 2 to $4 \mathrm{hr}$. Following this stimulation period, a sample of the medium $(0.5 \mathrm{ml})$ was removed and centrifuged at $2000 \times$ $g$ to pellet any cellular material. An aliquot $(0.35 \mathrm{ml})$ was carefully removed from the uppermost portion of the centrifuge tube and kept at $-70^{\circ} \mathrm{C}$ until assayed. In the catecholamine experiments, ascorbic acid was added to protect against oxidation. This concentration (final concentration, $10^{-5} \mathrm{M}$ ) of ascorbic acid did not alter ACTH release itself nor did it significantly change the $\mathrm{pH}$ of the Hepes-buffered medium ( $\mathrm{pH}$ 7.4). Forskolin was dissolved in ethanol. The final concentration of ethanol in the medium was $0.1 \%$ which by itself did not affect $\Lambda \mathrm{CTH}$ release. For the cyclic AMP studies, after the preincubation period and washing, the cells were incubated with medium con- taining $0.5 \mathrm{mM}$ isobutylmethylxanthine (IBMX) with or without CRF $\left(10^{-7} \mathrm{M}\right)$ or other test agents for $30 \mathrm{~min}$. At the end of this time the medium was removed, and $1 \mathrm{ml}$ of $0.5 \mathrm{~N} \mathrm{HCl}$ was added. The cells were sonicated, and the samples were frozen for later analysis. Each experimental condition was performed in triplicate or quadruplicate, and each study was performed at least 3 times.

\section{AtT 20 cells}

For the treatment of AtT 20 cells, DMEM containing $10 \%$ fetal calf serum and $3 \mu \mathrm{g} / \mathrm{ml}$ of bacitracin with or without CRF $\left(10^{7} \mathrm{M}\right)$ was incubated for $18 \mathrm{hr}$. At the end of this time the cells were washed twice. For the ACTH release experiments, fresh medium with or without CRF, isoproterenol (prepared in $0.1 \%$ ascorbic acid), and forskolin were applied to cells for $60 \mathrm{~min}$. Al aliquot of medium was removed after the incubation period and analyzed for ACTH as described above. For cyclic AMP studies, after the washing, cells were incubated with medium containing IBMX $(0.5 \mathrm{mM})$ and test agents for $30 \mathrm{~min}$. The reaction was terminated, and cyclic AMP content was determined as described above.

\section{Radioimmunoassay}

$A C T H$. The radioimmunoassay for ACTH was performed using a kit kindly provided by Dr. S. Raiti of the National Hormone and Pituitary Agency as previously described (Reisine and Hoffman, 1983). Human ACTH 1-39 is iodinated by the chloramine-T method (Parker, 1976).

Cyclic AMP. Intracellular cyclic AMP content was measured by radioimmunoassay using a commercially available kit purchased from New England Nuclear (Boston, MA).

\section{Materials}

Ovine $\mathrm{CRF}$, arginine vasopressin, $\left[\mathrm{Asu}^{1,6}, \mathrm{Arg}^{8}\right]$ vasopressin, and vasoactive intestinal peptide were purchased from Peninsula Laboratories, Inc. (Belmont, CA). Forskolin and epinephrine were purchased from Sigma (St. Louis, MO).

\section{Results}

CRF desensitization. Cultured rat anterior pituitary cells respond in a dose-dependent fashion to ovine CRF by secreting ACTH into the medium (half-maximal stimulation of ACTH release at $3 \mathrm{nM} \mathrm{CRF}$ ); cyclic AMP accumulation within the pituitary cells was similarly increased by CRF (half-maximal stimulation of cyclic AMP accumulation at $1 \mathrm{nM}$ CRF) (Fig. 1). In order to learn whether pre-exposure of these cells to CRF results in an altered response to subsequent CRF challenge, the cells were first incubated with $100 \mathrm{nM}$ CRF for $6 \mathrm{hr}$, washed with medium, and then rechallenged with varying concentrations CRF for $3 \mathrm{hr}$. CRF-induced release was markedly diminished, and no further stimulation by CRF of intracellular cyclic
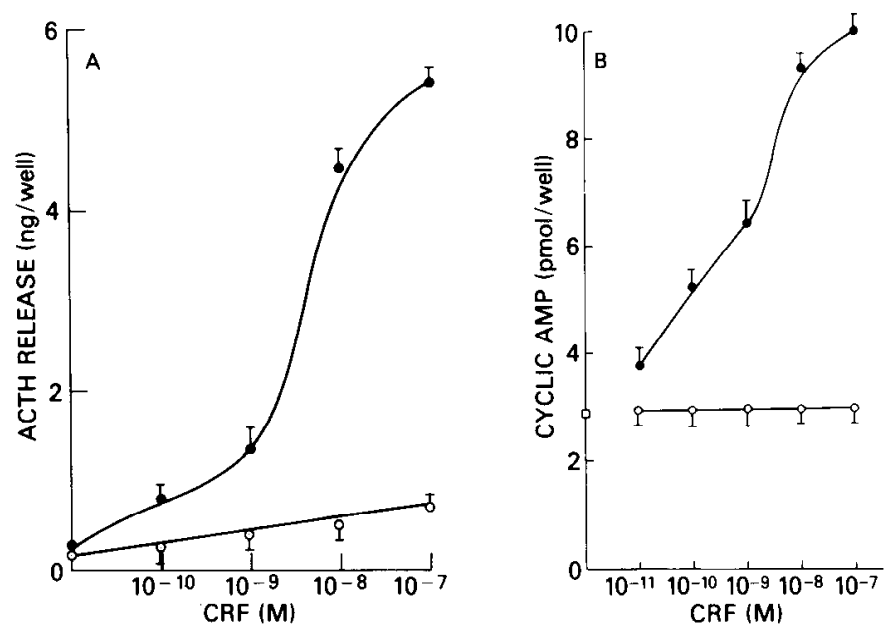

Figure 1. ACTH release $(A)$ and cyclic AMP accumulation $(B)$ after CRF stimulation by cultured rat anterior pituitary cells which were first exposed to medium alone (O) or to $100 \mathrm{nM} C R F(O)$ for $6 \mathrm{hr}$. 
Figure 2. Time course of CRF desensitization of ACTH release $(A)$ and cyclic AMP accumulation $(B)$ in pituitary cells which had been pre-exposed to 10 nM CRF for varying periods of time, washed with medium, and then restimulated with $100 \mathrm{nM}$ CRF. Control cells were pre-exposed to medium without added CRF. Basal and CRF-stimulated ACTH release in controls were $0.51 \pm 0.04$ and $5.6 \pm 0.8 \mathrm{ng}$ of $\mathrm{ACTH} /$ $\mathrm{ml}$, respectively. Basal and CRF-stimulated cyclic AMP accumulation in control cells were $2.8 \pm 0.4$ and $10.2 \pm 1.4 \mathrm{pmol} /$ well, respectively. Control basal and CRF-stimulated ACTH release and cyclic AMP formation were the same throughout the time course.

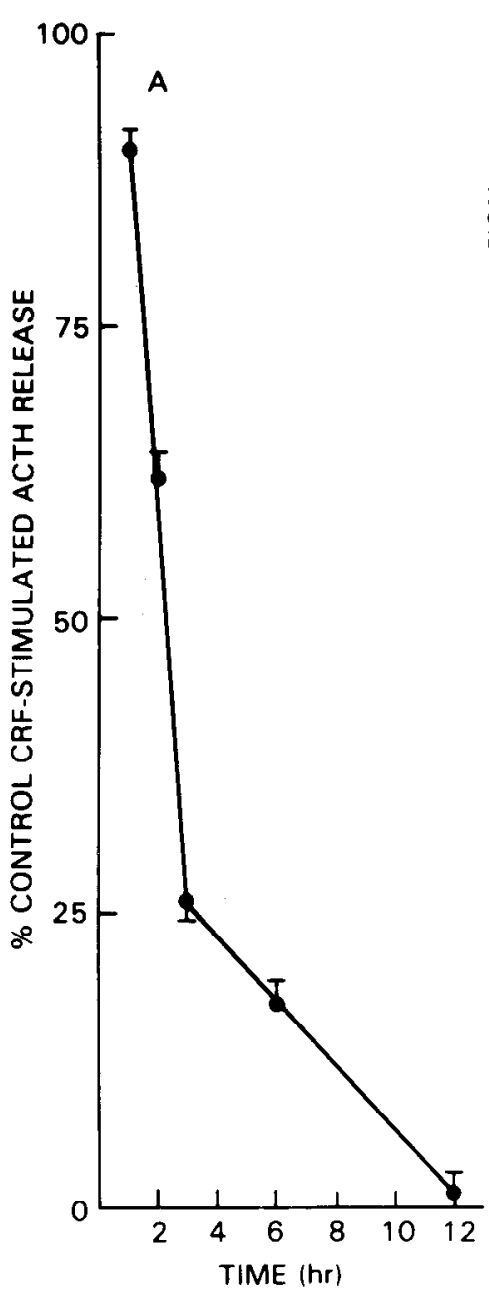

AMP accumulation occurred in those cells which had prior CRF exposure (Fig. 1), indicating desensitization of both ACTH release and cyclic AMP response. Desensitization occurs rapidly. While $50 \%$ desensitization of CRF-induced ACTH release is seen within 3 to $4 \mathrm{hr}$ of CRF exposure, similar desensitization for intracellular cyclic AMP accumulation is apparent by $1 \mathrm{hr}$ (Fig. 2). Since relatively high concentrations of CRF were used in these initial studies, it was important to determine whether lower, more physiologic levels of CRF could also desensitize anterior pituitary cells. In Figure 3, cells were incubated with varying concentrations of $\mathrm{CRF}$ for $3 \mathrm{hr}$ and then re-exposed to a maximally stimulatory dose of CRF (100 nM). Desensitization to both ACTH release and cyclic AMP accumulation is apparent when cells have been pre-exposed to as little as 1 to $10 \mathrm{pM}$ $\mathrm{CRF}$, indicating that CRF desensitization is not just a manifestation of pharmacologic levels of the hypothalamic peptide. ( $\mathrm{ED}_{50}$ values: $\mathrm{ACTH}$ release, $500 \pm 150$ pM; cyclic AMP accumulation, $50 \pm 20 \mathrm{pM}$ ).

To demonstrate that CRF desensitization is the most likely explanation for the above findings, it is necessary to show that the ACTH reserves were still present and had not been exhausted during the preincubation period. Table 1 shows the total amount of ACTH (intracellular plus medium) per well is unchanged in those cells which had been pre-exposed to 0.01 to $1 \mathrm{nM}$ CRF as compared to those which had been incubated with vehicle alone. There was a slight tendency for those cells treated with 10 to $100 \mathrm{nM}$ CRF to have less total ACTH content (Table I); however, this difference did not reach statistical significance (Student's $t$ test, $p>0.05$ ). The amount of intracellular immunoreactive ACTH was much greater than the quantity which was secreted in all CRF-pretreated cells, indicating that depletion of intracellular ACTH stores could not account for the desensitization. Cells which are homologously desensitized to CRF were nonetheless responsive to other ACTH-releasing factors. Epinephrine stimulated ACTH release equally well from control cells or from cells pretreated with $100 \mathrm{nM}$ CRF for $3 \mathrm{hr}$ (control basal $=0.40 \pm 0.06$; epinephrine stimulated $=0.81 \pm 0.12$; CRF-pretreated basal $=$ $0.35 \pm 0.04$; epinephrine stimulated $=0.85 \pm 0.09$, all in nanograms of ACTH/ml). Similarly, forskolin (Fig. 4), an agent proposed to activate the catalytic subunit of adenylate cyclase directly (Seamon and Daly, 1981), stimulated ACTH secretion to that same extent from control cells or from cells which had been pretreated with CRF.

To determine whether CRF desensitization occurred in a homogeneous population of corticotrophs, CRF was applied to AtT 20 cells for $18 \mathrm{hr}$ at a concentration that produced maximal desensitization in the primary cultures. As shown in Fig. 5, $\mathrm{CRF}$ produces a potent $\left(\mathrm{ED}_{50}\right.$ value $\left.=0.5 \pm 0.1 \mathrm{nM}\right)$ stimulation of ACTH release in control cells. After CRF pretreatment, the level of ACTH release in response to CRF was greatly diminished. Nonetheless, the ability of the $\beta$-adrenergic agonist isoproterenol to release ACTH was not affected by CRF pretreatment (Table II). Preincubation of AtT 20 cells with CRF also reduced the subsequent ability of CRF to increase cyclic AMP accumulation whereas the response to isoproterenol was unchanged. To confirm the lack of cross-desensitization between CRF and $\beta$-adrenergic receptors, AtT 20 cells were pretreated with isoproterenol $\left(10^{-6} \mathrm{M}\right)$ for $18 \mathrm{hr}$ (Table II). While these pretreated cells were refractory to $\beta$-adrenergic stimulation, 

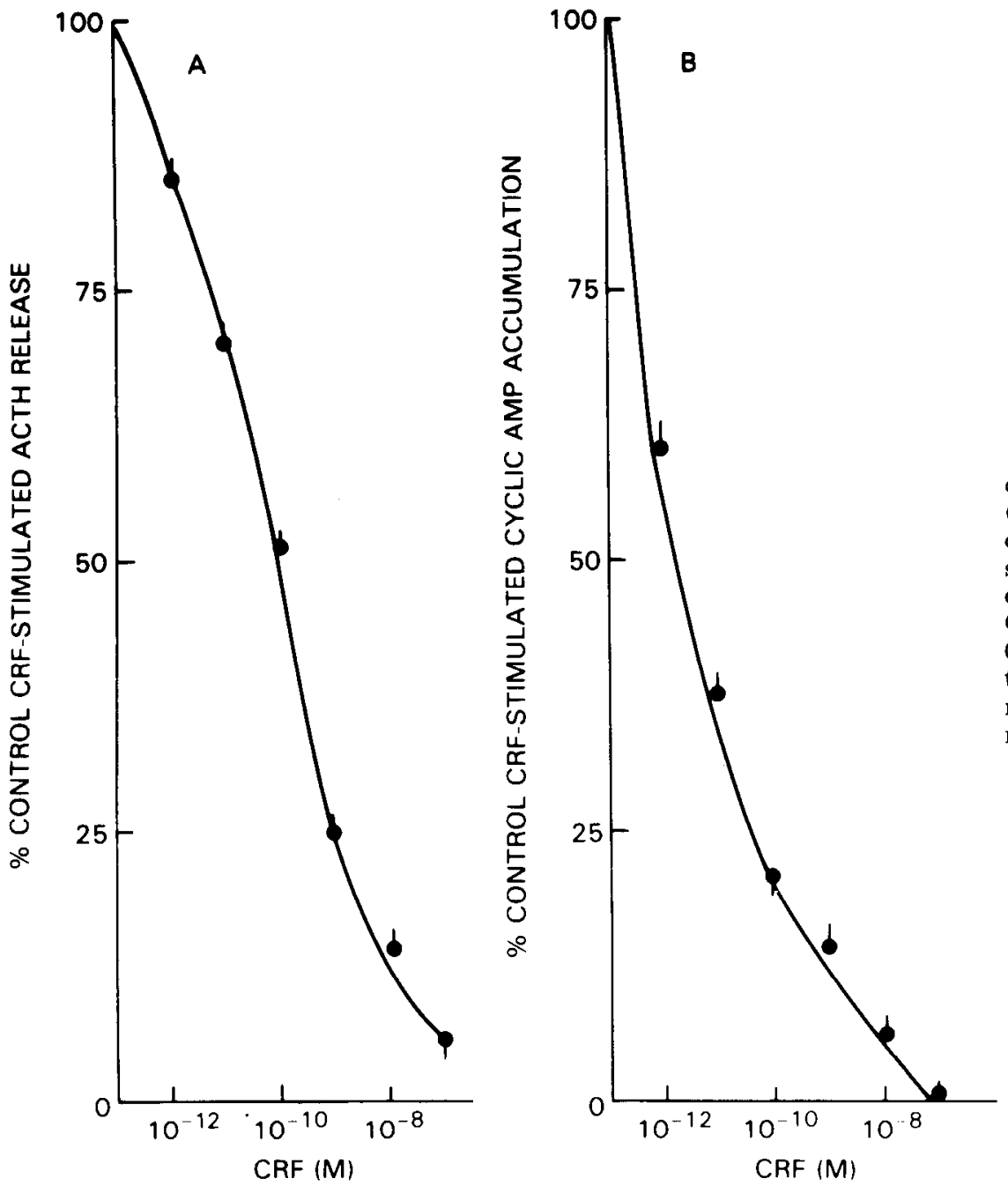

TABLE I

ACTH immunoreactive content after CRF treatment

Values are mean $\pm \mathrm{SE}(n=3)$. Cultured pituitary cells were treated with CRF $\left(10^{-7} \mathrm{M}\right)$ for $3 \mathrm{~h}$, washed, and then restimulated for $2 \mathrm{hr}$ with (Stimulated) or without (Basal) CRF $\left(10^{-7} \mathrm{M}\right)$.

\begin{tabular}{|c|c|c|c|c|}
\hline \multirow{2}{*}{$\begin{array}{c}\mathrm{CRF} \\
\text { Concentration }\end{array}$} & & \multicolumn{3}{|c|}{ ACTH Immunoreactivity } \\
\hline & & Medium & Tissue & Total \\
\hline & & \multicolumn{3}{|c|}{$n g /$ well } \\
\hline \multirow[t]{2}{*}{0} & Basal & $0.44 \pm 0.06$ & $11.1 \pm 0.6$ & 11.5 \\
\hline & Stimulated & $2.00 \pm 0.20$ & $10.0 \pm 0.3$ & 12.0 \\
\hline \multirow[t]{2}{*}{$10^{-11}$} & Rasal & $0.29 \pm 0.03$ & $9.4 \pm 0.6$ & 10.7 \\
\hline & Stimulated & $1.52 \pm 0.10$ & $9.8 \pm 0.6$ & 11.3 \\
\hline \multirow[t]{2}{*}{$\cdot 10^{-10}$} & Basal & $0.38 \pm 0.06$ & $11.4 \pm 0.7$ & 11.8 \\
\hline & Stimulated & $1.24 \pm 0.12$ & $9.3 \pm 0.9$ & 10.6 \\
\hline \multirow[t]{2}{*}{$10^{-9}$} & Basal & $0.29 \pm 0.08$ & $10.8 \pm 1.2$ & 11.1 \\
\hline & Stimulated & $1.01 \pm 0.07$ & $10.2 \pm 0.4$ & 11.2 \\
\hline \multirow[t]{2}{*}{$10^{-8}$} & Basal & $0.29 \pm 0.07$ & $9.6 \pm 0.9$ & 9.9 \\
\hline & Stimulated & $0.66 \pm 0.01$ & $9.2 \pm 0.8$ & 9.9 \\
\hline \multirow[t]{2}{*}{$10^{-7}$} & Basal & $0.56 \pm 0.10$ & $9.4 \pm 0.6$ & 9.9 \\
\hline & Stimulated & $0.58 \pm 0.11$ & $8.7 \pm 0.5$ & 9.3 \\
\hline
\end{tabular}

they responded normally to CRF. Moreover, forskolin-stimulated ACTH release and cyclic AMP formation was not altered by either agonist pretreatment.

Vasopressin potentiation of CRF desensitization in primary cultures of rat pituitary cells. Although CRF is one of the most potent ACTH-releasing factors discovered, other hypothalamic hormones may also stimulate ACTH secretion. By itself, AVP is a relatively weak $\mathrm{ACTH}$-secretagogue compared to ovine CRF, but when rat pituitary cells are exposed to both CRF and AVP, there is at least an additive effect on $\mathrm{ACTH}$ release (Fig. 6); our subclone of the AtT 20 line does not reproducibly respond to AVP (data not shown). Because of this enhancing ability in primary cultures, it was of interest to study how AVP might alter CRF-induced desensitization. Cultured rat anterior pituitary cells were first preincubated with $0.1 \mathrm{nM}$ CRF and varying concentrations of AVP for $3 \mathrm{hr}$. After the cells were washed with medium without these peptides, they were exposed to $100 \mathrm{nM}$ CRF alone. Cells pretreated with only CRF responded to subsequent CRF challenge with $40 \%$ less release of ACTH (Fig. 7). The presence of increasing amounts of AVP with $C R F$ in the pretreatment medium further reduced CRFstimulated ACTH release (Fig. 7). A substantial enhancement of CRF desensitization was evident with as little as $1 \mathrm{nM}$ AVP. Preincubation with $1 \mu \mathrm{M}$ AVP and $0.1 \mathrm{nM}$ CRF diminished the ability of CRF to stimulate ACTH release by $75 \%$. A potent and stable analogue of AVP, $\left[\mathrm{Asu}^{1,6}, \mathrm{Arg}^{8}\right]$ vasopressin also caused a dose-dependent potentiation of CRF-induced desensitization. Pretreatment with either AVP or $\left[\mathrm{Asu}^{1,6}, \mathrm{Arg}^{8}\right]$ vasopressin alone did not reduce the ACTH release response to CRF (data not shown).

Cultured cells were then exposed to varying concentrations of CRF with or without a high concentration of (1 $\mu \mathrm{M})$ AVP for a 3-hr preincubation period and then re-challenged with CRF alone. Addition of AVP to the preincubation mixture 


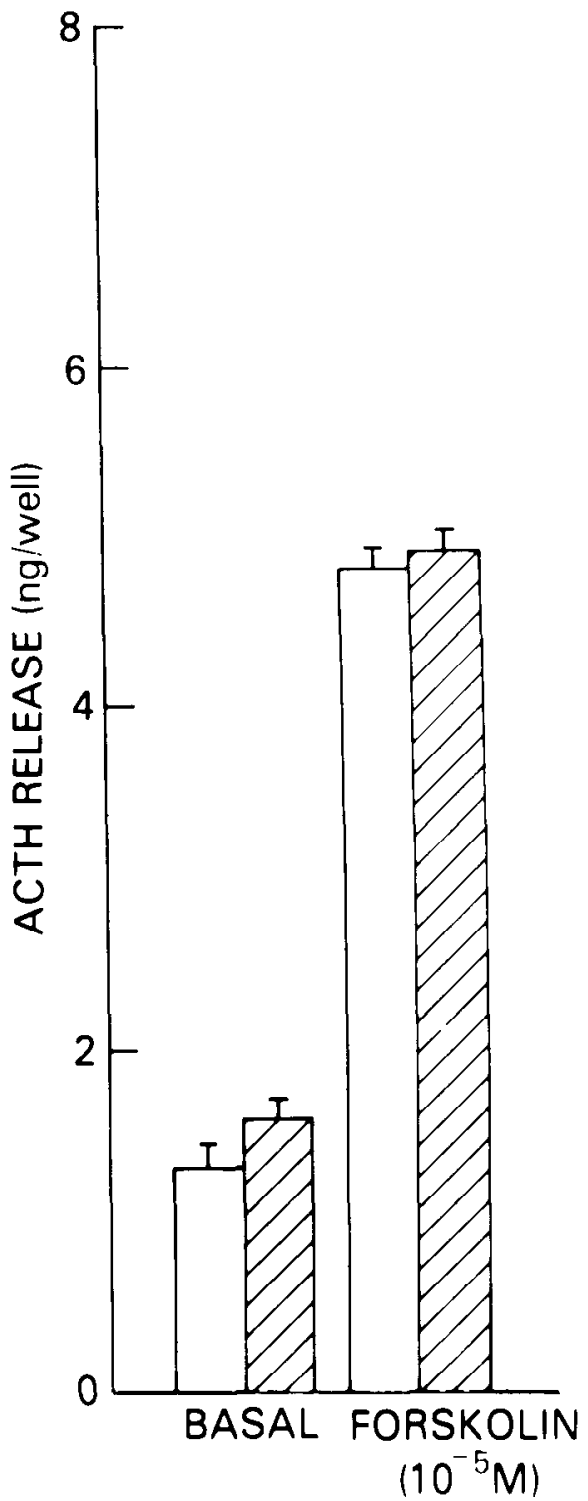

Figure 4. Forskolin stimulation of ACTH release in cells pre-exposed to $100 \mathrm{nM}$ CRF (ש) or to medium alone ( $\square$ ) and then incubated with forskolin.

allowed lower concentrations of CRF to produce a greater degree of desensitization. Figure 8 shows that the desensitization curve for AVP-and CRF-treated cells has been shifted to the left compared to CRF alone, with an apparent reduction in the $\mathrm{ED}_{50}$ value for $\mathrm{CRF}$-induced desensitization $\left(\mathrm{ED}_{50}\right.$ value: CRF alone, $700 \pm 150 \mathrm{pM}$; CRF + AVP, $20 \pm 15 \mathrm{pM})$. Utilizing a longer preincubation period $(6 \mathrm{hr})$, a reduction in the $\mathrm{ED}_{50}$ value for CRF-induced desensitization can be observed with much lower concentrations of AVP (pretreatment with CRF alone, $\mathrm{ED}_{50}=5 \times 10^{-11} \mathrm{M}$; co-incubation with $10^{-10} \mathrm{M}$ AVP, $\mathrm{ED}_{50}=1 \times 10^{-11} \mathrm{M}$; with $10^{-8} \mathrm{M} \mathrm{AVP}, \mathrm{ED}_{50}=5 \times 10^{-12} \mathrm{M}$; with $10^{-6} \mathrm{M}$ AVP, $\mathbf{E D}_{50}=1 \times 10^{-12} \mathrm{M}$ ).

In order to test the hypothesis that other ACTH-secretagogues could similarly enhance CRF desensitization, epinephrine $(1 \mu \mathrm{M})$ was preincubated with varying concentrations of CRF. No augmentation of CRF desensitization was noted (Fig. 9) with epinephrine co-incubation.

\section{Discussion}

We have studied the regulation of ACTH release using cultured rodent pituitary cells. Since primary cultures of rat pituitary cells respond to physiologic ACTH-stimulating and

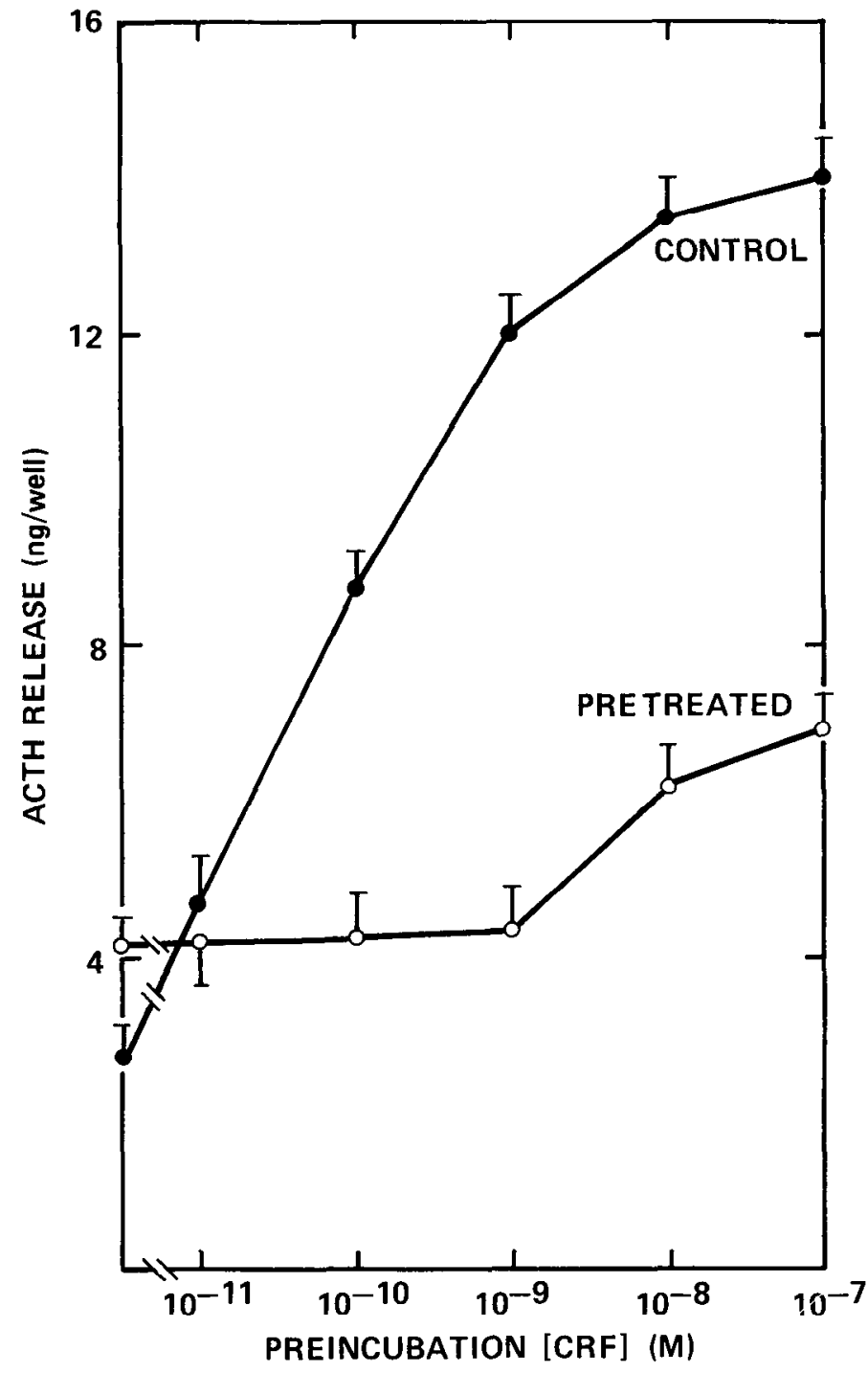

Figure 5. CRF desensitization of ACTH release in AtT 20 cells. Cells were exposed to $100 \mathrm{nM} \mathrm{CRF} \mathrm{(O)} \mathrm{or} \mathrm{medium} \mathrm{alone} \mathrm{(O)} \mathrm{for} 18 \mathrm{hr}$ and then rechallenged with varying concentrations of CRF.

inhibiting factors, including AVP, this system has proven to be a valuable tool for assessing the contributions of each neuroendocrine ACTH regulator separately, in isolation from other confounding influences. However, corticotrophs constitute less than $10 \%$ of all cells in such a system (Hyde et al., 1982), and paracrine effects from other pituitary cell types cannot be excluded. The AtT 20 cells, on the other hand, constitute a clonal corticotropinoma line which responds to many, but not all, of the regulators which modulate ACTH secretion in primary cultures. Vasopressin, for example, is not a potent secretagogue in the AtT 20/D16-16 cell line.

Our initial studies (Reisine and Hoffman, 1983) of CRF desensitization were performed in primary cultures of rat pituitary cells. In this system, CRF is the most potent ACTHsecretagogue, but AVP and catecholamines are also each able to elicit ACTH-directed corticotropin secretion (McCann and Brobeck, 1954; McDonald and Weise, 1956; Aizawa et al., 1982; Aguilera et al., 1983; Giguere and Labrie, 1983; Reisine et al., 1983). The ability of AVP to modulate ACTH release has been extensively investigated both in vivo and in vitro. While AVP itself is a rather weak secretagogue (Vale et al., 1983), its activity in vitro is enhanced by both serotonin (Spinedi and 
TABLE II

Desensilization of ALT 20 cells by CRF and isoproterenol

At $T 20$ cells were preincubated with CRF $\left(10^{-7} \mathrm{M}\right)$ or isoproterenol $\left(10^{-6} \mathrm{M}\right)$ and then rechallenged with $\mathrm{CRF}$, isoproterenol, or forskolin $\left(10^{-5} \mathbf{M}\right)$.

\begin{tabular}{|c|c|c|c|}
\hline \multirow[b]{2}{*}{ Challenge } & \multicolumn{3}{|c|}{ Preincubation Medium } \\
\hline & Control & $\operatorname{CRF}\left(10^{-7} \mathrm{M}\right)$ & $\begin{array}{l}\text { Isoproterenol } \\
\left(10^{-6} \mathrm{M}\right)\end{array}$ \\
\hline & \multicolumn{3}{|c|}{ ng/well } \\
\hline \multicolumn{4}{|l|}{ ACTH release } \\
\hline Control & $2.1 \pm 0.47$ & $2.6 \pm 0.30^{\alpha}$ & $2.1 \pm 0.14^{a}$ \\
\hline $\mathrm{CRF}\left(10^{-7} \mathrm{M}\right)$ & $6.7 \pm 0.20$ & $3.3 \pm 0.35^{b}$ & $6.3 \pm 0.27^{a}$ \\
\hline Isoproterenol $\left(10^{-6} \mathrm{M}\right)$ & $5.4 \pm 0.40$ & $5.9 \pm 0.61^{a}$ & $3.5 \pm 0.40^{b}$ \\
\hline \multirow[t]{2}{*}{ Forskolin $\left(10^{-4} \mathrm{M}\right)$} & $4.3 \pm 0.20$ & $4.7 \pm 0.28^{a}$ & $4.36 \pm 0.21^{\circ}$ \\
\hline & \multicolumn{3}{|c|}{$\mathrm{pmol} / \mathrm{well}$} \\
\hline \multicolumn{4}{|l|}{ Cyclic AMP } \\
\hline Control & $24 \pm 2.8$ & $36 \pm 6.0^{a}$ & $37 \pm 2.5^{a}$ \\
\hline $\operatorname{CRF}\left(10^{-7} \mathrm{M}\right)$ & $188 \pm 14.2$ & $87 \pm 2.0^{c}$ & $165 \pm 12.5^{a}$ \\
\hline Isoproterenol $\left(10^{-6} \mathrm{M}\right)$ & $159 \pm 9.0$ & $146 \pm 11.5^{a}$ & $48 \pm 7.2^{c}$ \\
\hline Forskolin $\left(10^{-5} \mathrm{M}\right)$ & $1364 \pm 122$ & $1072 \pm 101^{\circ}$ & $1101 \pm 98^{a}$ \\
\hline
\end{tabular}

${ }^{a}$ Not significantly different from control preincubation.

${ }^{b}$ Difference between control and medium, $p<0.05$.

${ }^{\mathrm{C}}$ Difference between control and medium, $p<0.005$.

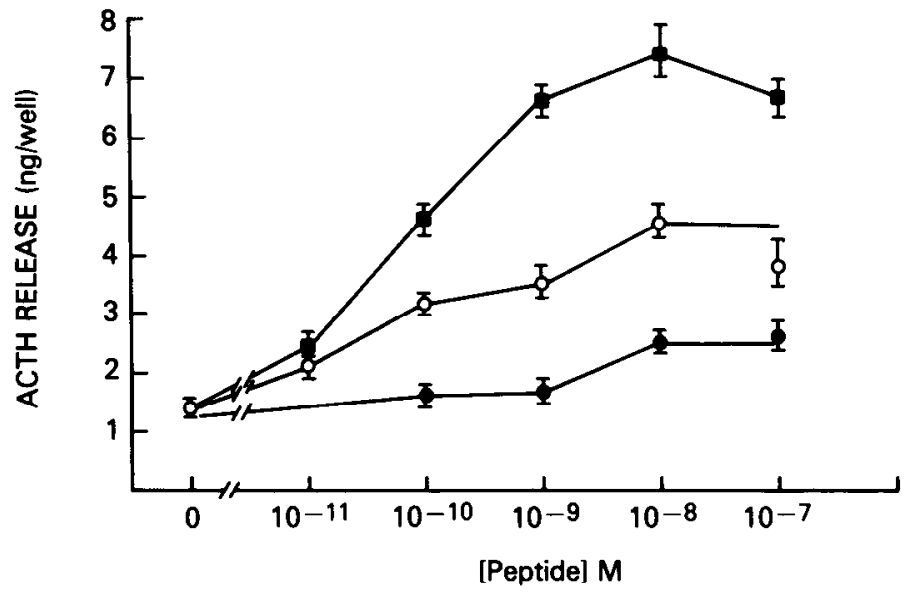

Figure 6. ACTH release stimulated by 3 -hr exposure to CRF (O), $\operatorname{AVP}(\bullet)$, and CRF plus AVP (ם).

Negro-Vilar, 1983) and vasoactive intestinal peptide (White et al., 1982). Numerous studies, including this present investigation, have shown that AVP has an additive if not potentiating effect on ovine CRF-induced ACTH release from primary cultures of pituitary cells. While CRF-stimulated ACTH secretion is preceded by the intracellular accumulation of cyclic AMP (Labrie et al., 1982; Reisine et al., 1982), AVP alone does not increase cAMP levels (Giguere and Labrie, 1982). When AVP is coincubated with $\mathrm{CRF}$, however, there is a potentiation of CRF-mediated cAMP accumulation (Giguere and Labrie, 1982). The possible physiologic importance of this enhancing interrelationship is further underlined by the recent discovery of Roth et al. (1982), who have shown that some neurons in the paraventricular nucleus contain both CRF and AVP. Moreover, this co-localization is enhanced by adrenalectomy (Kiss et al., 1984). Depolarization of these CRF- and AVP-containing neurons whose cell bodies terminate in the median eminence could result in the simultaneous release of both peptides into the hypothalamic-hypophyseal portal circulation where they might reach the corticotroph contemporaneously, thereby potentiating each other's ACTH-releasing ability. Thus, the corticotroph may be programmed to respond in a graded fashion to one or more of several stimulating hypothalamic hormones, and the amount of ACTH released by the pituitary could be a

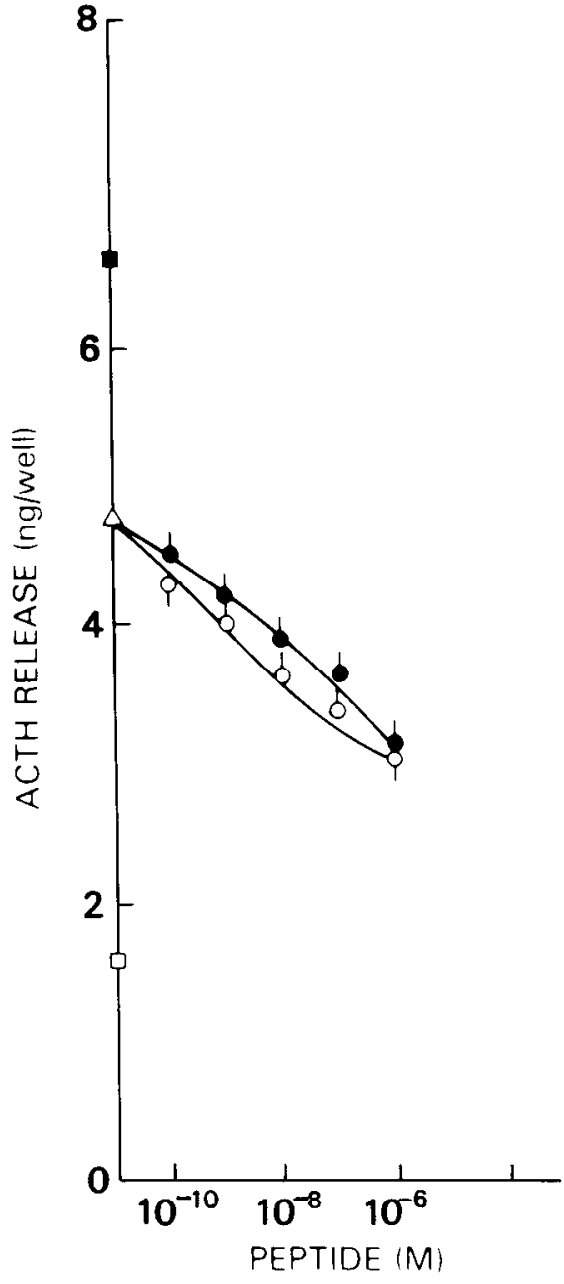

Figure 7. Vasopressin potentiation of CRF-induced desensitization. Anterior pituitary cells were pre-exposed for $3 \mathrm{hr}$ to $0.1 \mathrm{nM} \mathrm{CRF}$ and varying concentrations of AVP (•) or $\left[\mathrm{Asu}^{1,6}, \mathrm{Arg}^{8}\right]$ vasopressin $(\mathrm{O})$, a stable AVP analog. The cells were washed and then incubated with 100 nM CRF or medium alone for $3 \mathrm{hr}$. Control basal ( $\square$ ) or $100 \mathrm{nM} C R F$ stimulated $(\square)$ values as well as CRF pretreated, CRF-stimulated $(\triangle)$ values are represented on the $y$ axis.

function both of the concentration of any single stimulator and of the combination of ACTH-secretagogues which are secreted from the brain into the portal circulation.

Under conditions of more chronic stimulation, however, the regulation of $\mathrm{ACTH}$ release is complicated by changes in the corticotroph's responsiveness to its trophic and inhibitory hormones. As our studies in primary cultures and AtT 20 cells have demonstrated, exposure (within $4 \mathrm{hr}$ ) to relatively low concentrations of CRF results in substantial desensitization to further stimulation. In primary culture of rat pituitary cells, intracellular cyclic AMP accumulation, one potential mediator of ACTH release, is more rapidly desensitized than is hormone secretion itself. By $2 \mathrm{hr}$ of CRF pre-exposure, CRF-directed cyclic AMP accumulation has been desensitized by $70 \%$, while ACTH release is diminished by only $35 \%$ (Fig. 2). If ACTH secretion is dependent upon cyclic AMP, these data could suggest that CRF desensitization initially involves either an uncoupling of CRF receptors from adenylate cyclase or a loss of CRF receptors. There then follows a time lag in the desensitization of the ACTH release response, possibly because the cyclic nucleotide made in response to CRF stimulation is normally in excess of the amount needed for corticotroph secretion. We have previously shown that this desensitization is shortlived and is totally reversed approximately $1 \mathrm{hr}$ after the cells 


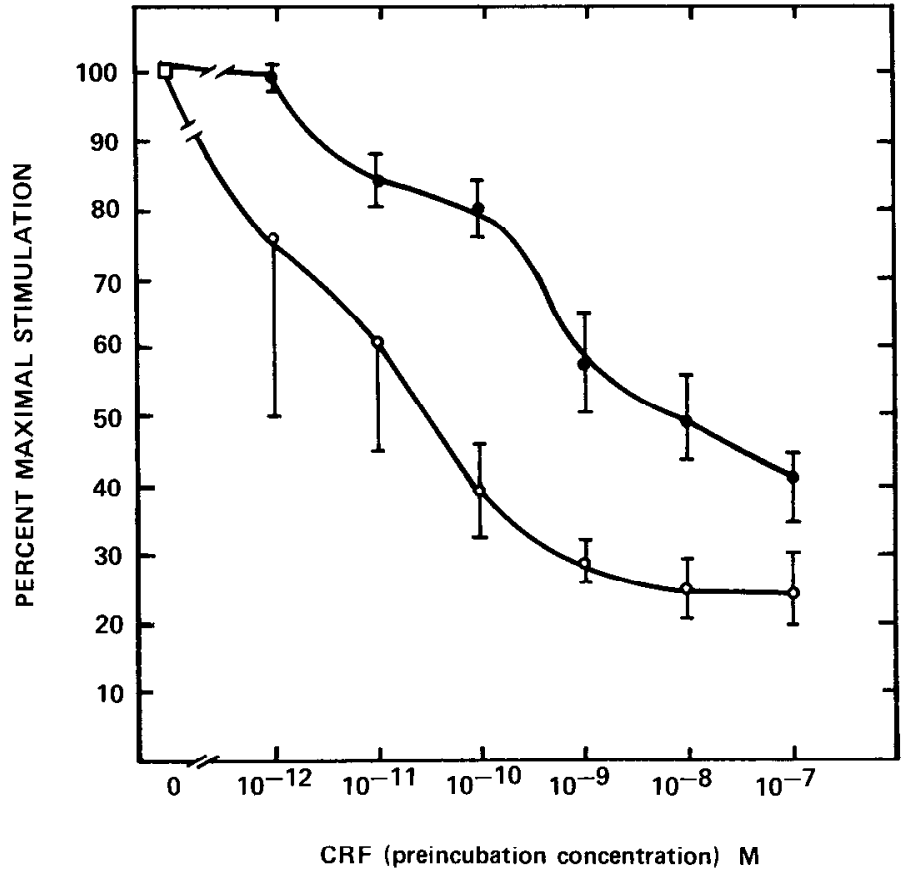

Figure 8. Desensitization of ACTH release by varying concentrations of CRF alone or with $10^{-6} \mathrm{M}$ AVP. Cells were pre-exposed to CRF (O) or CRF plus AVP $(1 \mu \mathrm{M})(\mathrm{O})$ for $3 \mathrm{hr}$, washed with medium alone, and then reexposed to $100 \mathrm{nM}$ CRF for $3 \mathrm{hr}$. Results are expressed as per cent maximal stimulation. The graph represents the mean of three separate experiments \pm SEM. In each experiment, triplicate determinations were made at each concentration of CRF.

have been removed from a CRF-containing milieu (Reisine and Hoffman, 1983). Wynn et al. (1983) recently reported that radiolabeled ${ }^{125}{ }^{1}$ - $\mathrm{Tyr}^{\circ}$-CRF binding to rat pituitary membranes is abolished 4 days after adrenalectomy. If glucocorticoid replacement commenced directly after adrenalectomy, ${ }^{125} \mathrm{I}-\mathrm{Tyr}^{\circ}$ CRF binding was maintained. These investigators hypothesized that adrenalectomy resulted in hypersecretion of CRF which ultimately led to down-regulation of $\mathrm{CRF}$ receptors; dexamethasone treatment prevented increased hypothalamic secretion of CRF and, thus, CRF receptor number was unchanged. In that study, the untreated adrenalectomized rats were not given CRF to learn if functional desensitization to CRF had occurred. Recently, Rivier and Vale (1983a) have shown that prior injection of CRF in rats reduces the subsequent ability of CRF to stimulate in vivo ACTH release. Taken together, these studies show that CRF desensitization may occur under physiologic conditions. It must be noted that ovine CRF differs from the newly described rat $\mathrm{CRF}$ by seven of 41 amino acids; nonetheless, the bioactivity of the two hormones in the rat appears to be identical (Rivier et al., 1983). Still, the kinetics of desensitization described herein may reflect the fact that ovine CRF is a CRF "analog" to the rat and therefore may have somewhat different receptor occupancy dynamics as compared to rat CRF.

Despite this profound desensitization induced by the most potent $\mathrm{ACTH}$-secretagogue, $\mathrm{CRF}$, the corticotroph is still able to respond to other trophic stimuli, such as $\beta$-catecholamines. In CRF-desensitized AtT 20 cells, the cyclic AMP-generating system, as measured by the response to forskolin, is also intact, further substantiating the homologous nature of CRF-induced desensitization. In addition, isoproterenol-induced desensitization of ACTH release is also specific, since cells which are desensitized to the effects of catecholamines respond normally to CRF. These data are consistent with a paradigm of multiple ACTH-secretagogues, each stimulating a specific cell-membrane receptor, which may or may not be independently linked

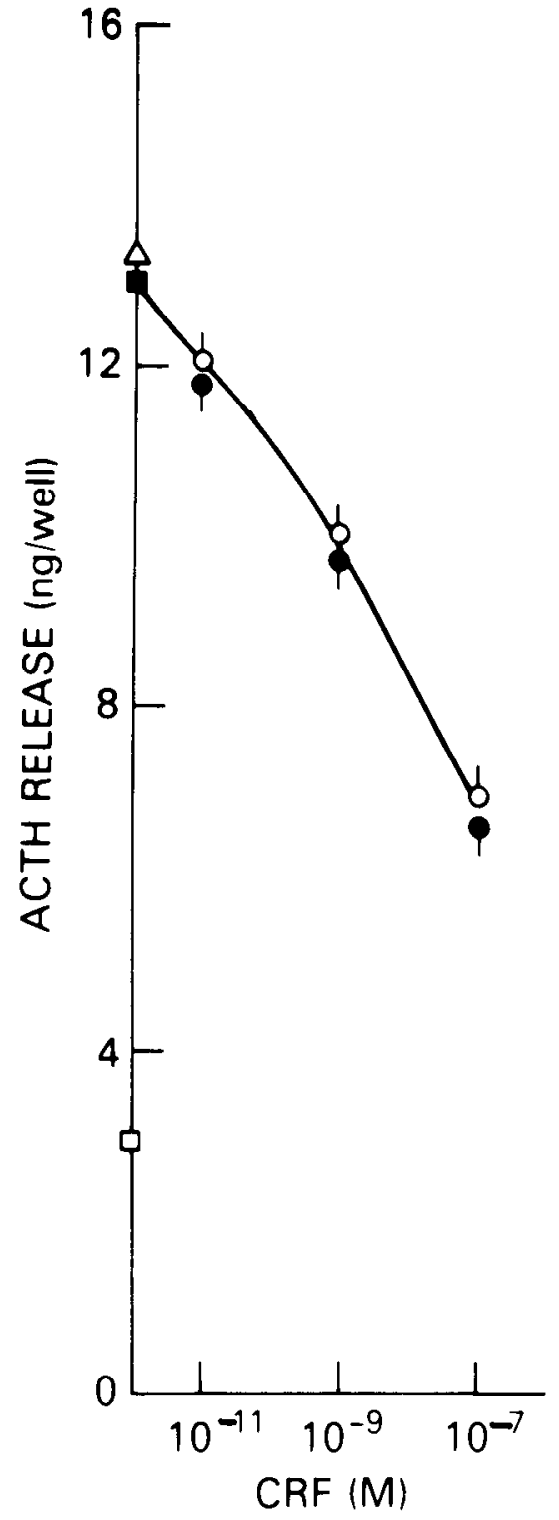

Figure 9. Effect of epinephrine on CRF-induced desensitization. Cells were pre-exposed for $3 \mathrm{hr}$ to varying concentrations of CRF with (O) or without (1) added $1 \mu \mathrm{M}$ epinephrine. After washing, the cells were stimulated with $100 \mathrm{nM} \mathrm{CRF}$ for $3 \mathrm{hr}$. Values for control basal (D) and CRF-stimulated (D) as well as cells pre-exposed to $1 \mu \mathrm{M}$ epinephrine and then stimulated with CRF $(\Delta)$ are represented on the $y$ axis.

to adenylate cyclase (Heisler et al., 1982). Desensitization to a single neurohormone may not interfere with stimulation by another ACTH-releasing hormone. In the AtT 20 mouse corticotropinoma line, we have shown that $\beta$-adrenergic agonists homologously desensitize their own ACTH-secreting capability by first uncoupling the receptor from adenylate cyclase and later down-regulating the number of $\beta$ receptors (Heisler et al., 1983b; Reisine and Heisler, 1983). The inhibitory effects of somatostatin are similarly desensitized in the tumor cells (Reisine and Axelrod, 1983).

Since desensitization also occurs in vivo (Rivier and Vale, 1983a), the ability of the corticotroph to become desensitized to a specific signal might theoretically allow for discriminant release of $\mathrm{ACTH}$ in situations in which the pituitary secretes ACTH in response to a wide range of stresses (Palkovits, 1977). For example, if different types of stress were associated with or mediated via distinct hypothalamic neurohormones, the 
organism could adapt to chronic stress of a particular sort with desensitization to that particular ACTH-releasing factor. Should a different sort of stress, associated with a separate releasing factor, then supervene, the pituitary could still respond by releasing ACTH despite being desensitized to the first neurohormone. Thus, homologous desensitization allows for both adaptation to long term stimuli while simultaneously providing the capacity to respond to a novel stress.

Evidence is now accumulating that further substantiates the concept that different kinds of stress may be mediated by different sets of ACTH-releasing factors. Rats which were pretreated with a potent AVP antagonist showed no deficit in the hypothalamic-pituitary-adrenal response to novelty stress (Mormede, 1983), but showed more than a $50 \%$ decrement in ACTH release $20 \mathrm{~min}$ after ether stress (Rivier and Vale, 1983c).

While CRF-induced desensitization does not alter the capacity of the corticotroph to respond to other trophic hormones, the ability of very low concentrations of CRF to desensitize its own action is greatly enhanced by AVP in primary cultures of rat pituitary cells. The mechanism by which AVP exerts this effect is unknown, but it is of interest that at low doses of AVP (1-10 nM), the peptide is an extremely weak ACTH-secretagogue (Fig. 6), but a potent enhancer of CRF-directed corticotropin release (after brief exposure) (Fig. 6) and of CRFinduced desensitization (after chronic stimulation). It is possible that AVP directly increases CRF receptor number or affinity or that it enhances coupling between CRF receptors and adenylate cyclase. Further information concerning the cellular mechanisms for this cooperative interaction awaits sensitive peptide receptor measurements. The ability to enhance CRF desensitization is not shared by all of the other ACTH-releasing hormones; epinephrine, for example, has no effect in this regard. Since AVP and CRF are occasionally co-localized within and possibly co-secreted by the same hypothalamic neurons, it is possible that chronic firing of such neurons would lead to more rapid desensitization of $\mathrm{ACTH}$ relcase than would long term release of CRF alone. Our data suggest that the major role of AVP at the corticotroph is to augment and fine tune CRF activity and not to release ACTH in the absence of CRF.

\section{References}

Aguilera, G., J. P. Harwood, J. X. Wilson, J. Morell, J. H. Brown, and K. J. Catt (1983) Mechanisms of action of corticotropin-releaasing factor and other regulators of corticotropin release in rat pituitary cells. J. Biol. Chem. 258: 8039-8045.

Aizawa, T., N. Yasuda, M. A. Greer, and W. H. Sawyer (1982) In vivo adrenocorticotropin-releasing activity of neurohypophyseal hormones and their analogs. Endocrinology 110:98-104.

Bilezikjian, L. M., and W. W. Vale (1983) Glucocorticoids inhibit corticotropin-releasing factor-induced production of adenosine $3^{\prime}, 5^{\prime}$ monophosphate in cultured anterior pituitary cells. Endocrinology 113: 657-662.

Giguere, V., and F. Labrie (1982) Vasopressin potentiates cyclic AMP accumulation and ACTH release induced by corticotropin-releasing factor (CRF) in rat anterior pituitary cells in culture. Endocrinology 111: $1752-1754$.

Giguere, V., and F. Labrie (1983) Additive effects of epinephrine and corticotropin-releasing factor (CRF) on adrenocorticotropin release in rat anterior pituitary cells. Biochem. Biophys. Res. Commun. 110: $456-462$.

Giguere, V., F. Labrie, J. Cote, D. H. Coy, J. Suecras-Diaz, and A. V. Schally (1982) Stimulation of cyclic AMP accumulation and corticotropin release by synthetic ovine corticotropin-releasing factor in rat anterior pituitary cells: site of glucocorticoid action. Proc. Natl. Acad. Sci. U.S.A. 79: 3466-3469.

Gillies, G., and P. J. Lowry (1982) Corticotropin-releasing hormone and its vasopressin component. Front. Neuroendocrinol. 7: 45-75.

Gillies, G. E., E. A. Linton, and P. J. Lowry (1982) Corticotropin releasing activity of the new CRF is potentiated several times by vasopressin. Nature 299: 355-357.
Heisler, S., T. D. Reisine, V. Y. H. Hook, and J. Axelrod (1982) Somatostatin inhibits multireceptor stimulation of cyclic AMP formation and adrenocorticotropin secretion in mouse pituitary tumor cells. Proc. Natl. Acad. Sci. U.S.A. 79: 6502-6506.

Heisler, S., L. Larose, and J. Morisset (1983a) Muscarinic cholinergic inhibition of cyclic AMP formation and adrenocorticotropin secretion in mouse pituitary tumor cells. Biochem. Biophys. Res. Commun. 114: 289-295.

Heisler, S., T. Reisine, and J. Axelrod (1983b) Desensitization of betareceptor mediated ACTH secretion in mouse pituitary tumor cells. Biochem. Biophys. Res. Commun. 111: 112-119.

Hyde, C. L., G. Childs, L. M. Wahl, Z. Naor, and K. J. Catt (1982) Preparation of gonadotroph-enriched cell populations from adult rat anterior pituitary cells by centrifugal elutriation. Endocrinology 111 : 1421-1423.

Kiss, J., E. Mezey, and L. Skirboll (1984) Corticotropin releasing factor (CRF)-immunoreactive neurons of the paraventricular nucleus become vasopressin positive following adrenalectomy. Proc. Natl. Acad. Sci. U.S.A. 81 : 1854-1858.

Labrie, F., B. Gagne, and G. Lefevre (1982) Corticotropin-releasing factor stimulates adenylate cyclase activity in the anterior pituitary gland. Life Sci. 31: 1117-1121.

McCann, S. M., and J. R. Brobeck (1954) Evidence for a role of the supraoptico-hypophyseal system in regulation of adrenocorticotrophic secretion. Proc. Soc. Exp. Biol. Med. 87: 318-324.

McDonald, R. K., and V. K. Weise (1956) Effect of arginine-vasopressin and lysine-vasopressin on plasma 17-hydroxycorticosteroid levels in man. Proc. Soc. Exp. Biol. Med. 92: 481-483.

Mormede, $P$. (1983) The vasopressin receptor antagonist dPTyr (Me) AVP does not prevent stress-induced ACTH and corticosterone release. Nature 302: $345-346$.

Palkovits, M. (1977) Neural pathways involved in ACTH regulation. Ann. N. Y. Acad. Sci, 297: 455-476.

Parker, C. W. (1976) Radioimmunoassay of Biologically Active Compounds, pp. 71-75, Prentice-Hall, New York.

Reisine, T., and J. Axelrod (1983) Prolonged somatostatin pretreatment desensitizes somatostatin's inhibition of receptor-mediated release of adrenocorticotropin hormone and sensitizes adenylate cyclase. Endocrinology 113: 811-813.

Reisine, T., and S. Heisler (1983) Densensitization of heta adrenergic receptors linked to adrenocorticotropin secretion. J. Pharmacol. Exp. Ther. 227: 107-114.

Reisine, T., and A. Hoffman (1983) Desensitization of corticotropinreleasing factor receptors. Biochem. Biophys. Res. Commun. 111: 919-925.

Reisine, T., S. Heisler, V. Y. H. Hook, and J. Axelrod (1982) Multireceptor-induced release of adrenocorticotropin from anterior pituitary tumor cells. Biochem. Biophys. Res. Commun. 108: 1251-1257.

Reisine, T. D., S. Heisler, V. Y. H. Hook, and J. Axelrod (1983) Activation of beta ${ }_{2}$-adrenergic receptors on mouse anterior pituitary tumor cells increases cyclic AMP synthesis and adrenocorticotropin release. J. Neurosci. 3: 725-732.

Rivier, C., and W. Vale (1983a) Influence of the frequency of ovine corticotropin-releasing factor administration on adrenocorticotropin and corticosterone secretion in the rat. Endocrinology 113: 14221426.

Rivier, C., and W. Vale (1983b) Interaction of corticotropin-releasing factor and arginine vasopressin on adrenocorticotropin secretion in vivo. Endocrinology 113: 939-942.

Rivier, C., and W. Vale (1983c) Modulation of stress-induced ACTH release by corticotropin-releasing factor, catecholamines and vasopressin. Nature 305: 325-327.

Rivier, J., J. Spiess, and W. Vale (1983) Characterization of rat hypothalamic CRF. Proc. Natl. Acad. Sci. U.S.A. 80: 4851-4855.

Roth, K. A., E. Weber, and J. D. Barchas (1982) Immunoreactive corticotropin-releasing factor (CRF) and vasopressin are colocalized in a subpopulation of the immunoreactive vasopressin cells in the paraventricular nucleus of the hypothalamus. Life Sci. 31: 18571860.

Seamon, K., and J. Daly (1981) Activation of adenylate cyclase by the diterpene forskolin does not require guanine nucleotide regulatory protein. J. Biol. Chem. 256: 9799-9801.

Spinedi, E., and A. Negro-Vilar (1983) Serotonin and adrenocorticotropin $(\mathrm{ACTH})$ release: direct effects at the anterior pituitary level and 
potentiation of arginine vasopressin-induced ACTH release. Endocrinology 112: 1217-1223.

Vale, W., J. Spiess, C. Rivier, and J. Rivier (1981) Characterization of a 41-residue ovine hypothalamic peptide that stimulates secretion of corticotropin and beta endorphin. Science 213: 1394-1397.

Vale, W., J. Vaughan, M. Smith, G. Yamamoto, J. Rivier, and C. Rivier (1983) Effects of synthetic ovine corticotropin-releasing factor, glucocorticoids, catecholamines, neurohypophyseal peptides and other substances on cultured corticotropic cells. Endocrinology 113: 11211131.
White, M. C., E. F. Adams, M. Loizen, and K. Mashiter (1982) Vasoactive intestinal peptide stimulates adrenocorticotropin release from human corticotropin cells in culture: interaction with arginine vasopressin and hydrocortisone. J. Clin. Endocrinol. Metab. 55: 967-972.

Wynn, P. C., G. Aguilera, J. Morell, and K. J. Catt (1983) Properties and regulation of high affinity pituitary receptors for corticotropinreleasing factor. Biochem. Biophys. Res. Commun. 110: 602-608.

Yates, F. E., S. M. Russell, M. F. Dallman, G. A. Hedge, S. M. McCann, and A. P. S. Dhariwal (1971) Potentiation by vasopressin of corticotrophin release induced by CRF. Endocrinology 88: 3-15. 